\title{
ОСОБЛИВОСТІ МІСЦЕВОЇ ПІДГОТОВКИ ШИЙКИ МАТКИ ДО ПОЛОГІВ
}

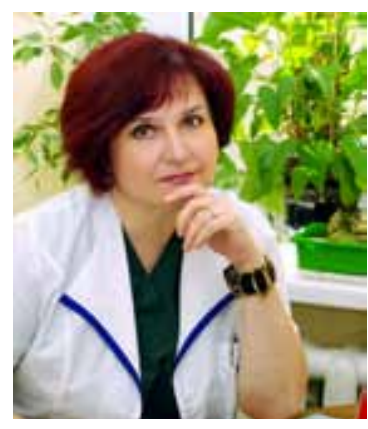

І.А. ЖАБЧЕНКО

д.мед.н., завідувач відділення патології вагітності та пологів Інституту предіатрії, акушерства та гінекології НАМН України учасний стан здоров'я та велика кількість акушерських і перинатальних проблем у жінок вимагають від лікарів забезпечення виношування вагітності та народження здорової дитини шляхом проведення родозбудження або програмованого ведення пологів. Важливим показником готовності організму вагітної до пологів є ступінь зрілості шийки матки (ШМ), оскільки саме період її розкриття (перший період пологів) великою мірою зумовлює результат процесу пологів для матері та новонародженого, тривалість пологів та частоту оперативного розродження.

Незріла ШМ не здатна до адекватного розкриття у відповідь на скорочення матки. Спроба проведення родозбудження за цих умов призводить до затяжних травматичних пологів, дистресу плода, оперативного втручання, інфрекційних ускладнень (хоріоамніоніт, ендометрит), пошкодження м'яких тканин родового каналу та травм новонародженого.

Визначення ступеня зрілості ШМ є досить суб'єктивним, залежить від досвіду лікаря, але навіть досвідчені фахівці можуть давати різну оцінку стану ШМ. Розроблено декілька оціночних шкал (бальних систем), серед яких найвідоміша та найбільш прийнятна шкала Бішопа. Більшість інших шкал включають майже ті ж самі параметри (довжина ШМ, розкриття зовнішнього вічка, консистенція, розташування шМ відносно вісі таза, місце розташування передлеглої частини плода), але надають кожному з них різну кількість балів.

За шкалою Бішопа розрізняють наступні стадії готовності ШМ: 0-5 балів - незріла ШМ, 6-8 балів - неповне дозрівання ШМ, 9-14 балів повністю зріла ШМ.

Для оцінки ступеня готовності організму жінки до пологів використовують також окситоциновий та маммарний тести, тест визначення величини опору ШМ до перемінного електричного струму, кольпоцитологічний тест. Однак усі зазначені тести мають свої недоліки, складні у виконанні або недосить інформативні.

Окрім пальпаторної оцінки зрілості ШМ, доцільно враховувати й рівень естрадіолу у крові вагітних напередодні розродження 3 метою більшої ефективності програмованих пологів [6]. Показаннями для призначення допологової підготовки найчастіше $є$ наступні ситуації:

переношена вагітність;

6 стани, що вимагають дострокового або програмованого розродження (соматичні захворювання, акушерська патологія - пізні гестози, імуноконфлікти, психоемоційне напруження);

скомпрометована ШМ (кріодеструкція, діатермокоагуляція в анамнезі);

(5) патологічний прелімінарний період під час попередніх пологів.

Численними дослідженнями доведено, що розкриття ШМ під час пологів є мультифакторним процесом, який включає значну кількість елементів, складних процесів на системному, тканинному, клітинному, генному та молекулярному рівнях. Серед них: денервація ШМ, її кровопостачання, локальне збільшення судинної проникності та діапедезу форменних елементів, збільшення у стромі числа лейкоцитів та макрофрагів і посилення їхньої функціональної активності, зміни в сполучнотканинній структурі екстрацелюлярного матриксу зі зростанням вмісту гіалуронової кислоти, збільшення гідрофрільності тканин зі схильністю колагену до дисперсії та підвищеної розтяжності тканин ШМ. Завершує цей процес тиск голівки плода та передніх навколоплідних вод на ШМ. Водночас відбуваються певні зміни в епітелії ШМ, спрямовані на запобігання ушкоджень та висхідного шляху інфікування $[1,5]$.

На думку Г.І. Брехмана (2010), усі зазначені процеси керовані генним ансамблем клітин, який змінює спрямованість процесів із прозапальних (розтяжність та розкриття ШМ під час пологів) на протизапальні (швидке відновлення структури ШМ після пологів).

За наявності вищезазначених показань вагітним може бути призначена підготовка ШМ до пологів з максимальним урахуванням усіх чинників процесу її розкриття.

Одним з напрямків підготовки ШМ до пологів $€$ застосування естрогенів із системним механізмом дії. Одразу слід зазначити, що у більшості зарубіжних літературних джерел даний метод розглядається більше в історичному, ніж у практичному аспекті, оскільки результати сучасних мультицентрових контрольованих досліджень свідчать про низьку ефективність цього методу [3, 4]. 
Тривалий час за часів СРСР у нашій країні широко використовували метод створення глюкозо-вітаміно-естрогено-кальцієвого фону (ГВЕКФ) вагітним 3 метою підготовки ШМ до пологів та профілактики слабкості пологової діяльності. Як гормональну складову ГВЕКФ використовували естрадіол. Така композиція препаратів мала вплинути на більшість ланок процесу підготовки жінки до пологів наприкінці вагітності та при аномаліях пологової діяльності. На сьогоднішній день в Україні цей метод майже не використовується, оскільки з'явилися більш сучасні ефективні засоби та методики, хоча в деяких країнах СНД він і досі має місце.

Водночас навряд чи можна заперечувати, що досвід минулих років із використанням естрогенів не слід одностайно відкидати, спи-
Під час вагітності головна складова частина тканин матки - хондроїтинсульфат та гіалуронова кислота (кислі мукополісахариди) - полімеризується в результаті дії гіалуронідази, що сприяє розщепленню колагенових волокон та збільшенню гідрофрільності тканин ШМ. Зміни складу основної речовини ШМ та часткове розсмоктування колагенових волокон починаються у її піхвовій частині, розповсюджуючись поступово від зовнішнього вічка до внутрішнього. У результаті цього ділянка внутрішнього вічка пом'якшується та розкривається [6]. У зазначених процесах значна роль належить естрогенним гормонам, які впливають на обмінні процеси та регулюють ріст матки, викликаючи гіперплазію та гіпертрофію ендометрія, беруть безпосередню участь у розвитку родового акту, сенсибілізуючи мат-

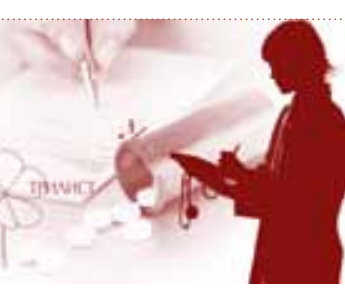

Сьогодні підготовка ШМ до пологів за допомогою естрогенів із системним механізмом дії вже майже не використовується, оскільки

більш сучасним методом $€$ застосування естрогенів локальної дії, зокрема проместрину - синтетичного похідного естрадіолу

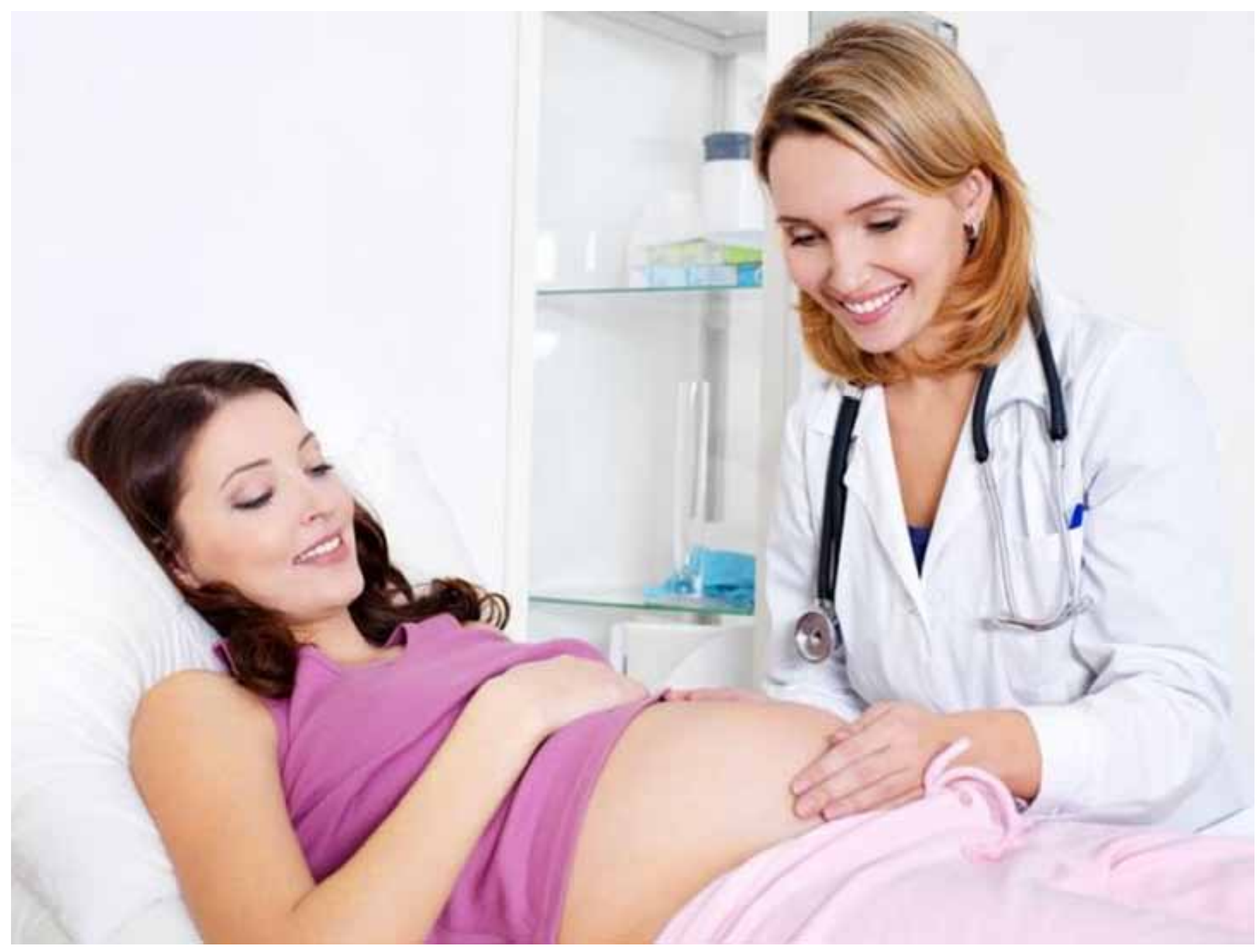

раючись хоча б на ті безсумнівні позитивні ефекти, які мають естрогенвмісні засоби у підготовці ШМ до пологів. Окрім того, не варто забувати ще й про фрізіологічність даного механізму. Протипоказаннями до застосування таких препаратів $€$ гормонозалежні пухлини статевих органів та молочних залоз, кровотечі неясного генезу, тромбози, емболії, порушення функції печінки, отосклероз. ку до дії окситоцину. Разом із тим естрогени впливають на сполучну тканину, призводячи до пом'якшення ШМ [7]. Чимало дослідників відзначали позитивний ефект від призначення естрогенів місцевої дії напередодні пологів [2]. Окрім безпосереднього впливу на тканини ШМ, позитивним є сприятлива дія достатнього місцевого рівня естрогенів на вагінальну екосистему, що вкрай важливо наприкінці 
вагітності, оскільки адекватно збалансований естрогенний рівень гарантує проліферацію та дозрівання вагінального епітелію, а також відповідне накопичення глікогену поживного субстрату для лактобактерій [7].

Перед пологами важлива функція естрогенів - вплив на процеси дозрівання ШМ, однак негативним є їх системний ефект щодо стану плода та формування подальшої лактації. Із цих позицій дуже цікавим є виключення системної дії при збереженні позитивних локальних ефектів естрогенів. Єдиним відомим натепер естрогеном, що має такі властивості, $€$ його синтетична похідна проместрин.

Проместрин - це ексклюзивна молекула $17 \beta$-естрадіолу диефіроксиду, що має виключно місцеву дію та не спричиняє системних естрогенних ефектів [7]. Останній факт $€$ принципово важливим у жінок на етапі лактогенезу та лактопоезу. Місцева дія проместрину базується на особливостях фрізичних властивостей його молекули, а саме: молекула проместрину, маючи ізоелектричну структуру (усі ОН-групи інактивовано СН3-групами), абсорбується < 1\% активної речовини (лише за рахунок поодиноких розривів у базальній мембрані).

Проместрин сприяє накопиченню глікогену, відновлює рівень лактобацил та фрізіологічний $\mathrm{pH}$, тобто відновлює трофріку слизової оболонки піхви, нормалізує біоценоз піхви. Відсутність системних ефектів проместрину (немає впливу на ендометрій, молочні залози, білковий і вуглеводний обмін та інші параметри гомеостазу) дозволяє рекомендувати його широкому загалу пацієнток із гінекологічними та екстрагенітальними проблемами.
Проместрин є запатентованою молекулою й випускається ексклюзивно заводами компанії «Терамекс» (Монако), що входять до складу корпорації Тева. У світі, в т.ч. і в Україні, проместрин представлено лише у складі препаратів місцевої дії Колпосептин та Колпотрофрін.

Досвід наших колег доводить ефективність препарату Колпосептин при використанні його при підготовці ШМ до пологів у порівнянні з інтравагінальним введенням прогестерону та створенням ГВЕКФ [2]. Так, середня тривалість дозрівання ШМ при використанні прогестерону була найбільш вираженою та швидкою - за 11,6 год сягала з 6 до 14 балів за шкалою Бішопа; при застосуванні проместрину ШМ готувалась до пологів більш плавно, але ефективно - 3 2 до 14 балів у середньому за 5,3 доби. Найменшим був ефрект при призначенні ГВЕКФ - за 12,5 доби вдалося змінити стан ШМ з 2 балів лише до 6 за шкалою Бішопа.

Таким чином, підсумовуючи огляд сучасних методів підготовки ШМ до пологів, слід зазначити, що остаточний вибір залишається за лікарем, оскільки необхідно враховувати такі чинники:

3 індивідуальні особливості вагітної;

3оказання до самої підготовки ШМ та початковий стан ШМ;

досвід використання певного методу підготовки ШМ до пологів в даній клініці;

можливості моніторингу стану ШМ протягом періоду її підготовки до пологів тощо.

Отже, наявність препаратів, що містять естроген з виключно місцевим ефектом, значно розширює терапевтичні можливості лікаря.
На сегодняшний день компания «Терамекс» (Монако) является подразделением корпорации Тева и специализируется на разработке и выпуске оригинальных лекарственных средств для женщин, в Т.ч. препаратов Колпосептин и Колпотрофин.

Колпотрофин выпускается в виде вагинальных капсул и вагинального крема. Содержит в своем составе проместрин и с успехом используется для подготовки ШМ к родам, восстановления эпителия ШМ после хирургического лечения ее эрозий, для заживления влагалища и ШМ после родов, у женщин в постменопаузе с урогенитальными расстройствами, а также для лечения синехий у девочек.

Колпосептин в отличие от Колпотрофина представляет собой вагинальные таблетки, содержащие наряду с проместрина 10 мг еще и антисептический компонент в виде
200 мг хлорхинальдола (антисептик с широким спектром действия). Такая комбинация позволяет не только достигать высокоэффективной эрадикации возбудителя, но и одновременно обеспечивать восстановление слизистой, а соответственно - нормальной микрофрлоры, и в конечном итоге снижает частоту рецидивов. Наиболее уместно его применение для лечения инфекционно-воспалительных заболеваний влагалища различного происхождения (кроме гонококкового), а также бактериального вагиноза и кандидоза легкой и средней степени тяжести и восстановления эпителия ШМ после хирургического лечения ее эрозий. Кроме того, Колпосептин может быть использован для подготовки ШМ к родам.

Подробная информация о препаратах содержится в инструкциях по медицинскому применению

\section{ЛІТЕРАТУРА}

1. Брехман Г.И. Шейка матки: преобразования в связи с родовым процессом // Жіночий лікар. - 2010. - № 6 (32). - С. 5-11.

2. Жук С.І., Сальніков С.М., Чечуга С.Б. Сучасна допологова підготовка шийки матки (інформаційний лист). - 2007. - Вип. 1, № 41

3. Хофмейр Д.Ю., Нейлсон Д.П., Алфиревич 3. и др.

Кокрановское руководство: Беременность и роды // Под общ. ред. Г.Т. Сухих. Пер. с англ. В.И. Кандрора, О.В. Ереминой. - М.: Логоссрера, 2010. -440 c.

4. Энкин М., Кейрс М., Нейлсон Д. и др. Руководство по эффективной помощи при беременности и рождении ребенка / / Пер. с англ. под ред. А.В. Михайлова. - СПб.: Петрополис, 2003. - 480 с.
5. Савицкий Г.А., Савицкий А.Г. Биомеханика физиологической и патологической родовой схватки. - СПб.: Элби-СПб, 2003. - 287 с. 6. Плоский А.Р., Авер Ж.К., Земляной И.Г., Усков С.И. Течение и исходы родов в зависимости от уровня эстрадиола в крови беременных женщин // Сб. научн. трудов и материалов международного научного симпозиума и научно-практической конференции «Современные перинатальные медицинские технологии в решении проблем демографической безопасности. Современные технологии инвазивной диагностики и лечения патологии плода». - Минск, 2010. - С. 127-128.

7. Romanini R. Traitement prolonge de la vaginite atrophique par promestriene // Gynecol. - 1980. - Vol. 31. - P. 627-631. 